\title{
Characteristics of Vowel Space and Speech Intelligibility in Patients with Spastic Dysarthria
}

\author{
Sungyun Kim ${ }^{\text {, }}$ Jung Hwan Kim ${ }^{\mathrm{b}}$, Do-Heung Ko \\ ${ }^{a}$ Department of Speech Pathology, Duru Barun Social Cooperative, Wonju, Korea \\ ${ }^{b}$ National Rehabilitation Center, Seoul, Korea \\ 'Division of Speech Pathology \& Audiology, Hallym University, Chuncheon, Korea
}

\author{
Correspondence: Jung Hwan Kim, MD, PhD \\ Korea National Rehabilitation Center, \\ 58 Samgaksan-ro, Gangbuk-gu, Seoul 142-884, \\ Korea \\ Tel: +82-2-901-1801 \\ Fax: +82-2-901-1591 \\ E-mail: view1492@gmail.com
}

Received: July 3, 2014

Revised: August 16, 2014

Accepted: September 18, 2014

This article was supported by the research grant from the Kangwon National University \& Hospital School of Medicine and is based on the thesis of the first author.

\begin{abstract}
Objectives: Characteristics of dysarthria include decreased speech intelligibility and changes in vowel space parameters, but details on spastic type have not been reported in Korea. The objective of this study is to determine if there is any difference in speech intelligibility or the parameters related to the vowel space between people with no speech disorders and patients with spastic dysarthria. Methods: This study consists of total 30 subjects, 15 in the spastic dysarthria group and 15 in the normal control group, comparing speech intelligibility, vowel space area, and related parameters (vowel articulatory index, formant centralization ratio $[\mathrm{FCR}]$, and $\mathrm{F}_{2}$ ratio). Results: First, for the interval scale of speech intelligibility at the level of context vowels, the control group had a median of 1.02 points and the patient group had a median of 2.07 points $(p<0.001)$. Second, the spastic dysarthria group had smaller vowel space area, smaller vowel articulatory index value, greater FCR, and smaller $F_{2}$ ratio than the normal group $(p<0.05)$. Conclusion: This study shows decreased speech intelligibility and vowel space in spastic dysarthria patients with objective data from vowel-space-related parameters (such as vowel space area itself, vowel articulatory index, formant centralization ratio, and $\mathrm{F}_{2}$ ratio).
\end{abstract}

Keywords: Dysarthria, Vowel space, Intelligibility, Acoustic analysis
경직형 마비말장애(spastic dysarthria)의 경우에 조음기관 근육 의 과대긴장(hypertonia)이나 과소긴장(hypotonia)으로 인해 특 정한 음소들을 조음하는 데 어려움을 나타낸다고 하였으며, Duffy (2005)는 혀나 입술, 하악의 협응이 부적절하여 모음의 왜곡이 심 하게 나타난다고 하였다.

마비말장애 환자의 구어적 평가방법으로 의사소통의 효율성을 나타내는 말 명료도(speech intelligibility)는 의사소통의 성공 정도 를 반영하는 지표이다. 이는 화자 및 청자의 개인적 경향, 대화 상황 시 소음의 정도, 메시지의 언어학적 특성, 메시지 전달매체 등과도 연관되며, 의사소통 상황에서 전달되는 메시지의 정확성에 미치는 주요 변수이다(Hustad, 2006, 2008). 즉, 화자가 전하는 구어신호를 청자 입장에서 얼마나잘 알아들을 수 있는가의 정도를 의미한다.

선행연구만으로는 마비말장애의 중증도가 심하여 말 명료도가 나쁠수록 마비말장애 환자가 발성하는 모음이 모음공간면적 등의
측면에서 음향학적으로도 일정한 방향성이 있는지, 또한 이것이 환 경(고립모음/문맥모음)에 따라 비슷한 패턴을 보이는지 여부를 제 시하지 못하고 있으며, 더욱이 마비말장애의 하위 유형(경직형 등) 에 대한 기술이 부족하다(Lee, 2010b).

말 운동장애 연구 영역에서 말 명료도는 임상적인 진단과 평가 그리고 치료전략으로 직접 연관되는 연구로서의 의미를 지니며, 기 능적인 의사소통 능력과 직결되는 주요 변수이기에, 다양한 언어학 적 조건 속에서의 말 명료도 연구가 요구된다고 하였다(Hustad, 2007).

현재 말 명료도 평가가 마비말장애 화자 발화에 대한 주관적인 평가인 반면에 음향학적 평가는 객관적인 평가로 모음의 포먼트 측 정 및 모음사각도 등의 모음공간에 대한 연구가 병행되고 있다. 특 히, 모음공간 면적(vowel space area)은 마비말장애 화자의 말 명료 도 혹은 모음의 정확한 조음과 관련이 있고, 말의 길이에 따른 모음 
공간면적에 차이가 있음이 보고되고 있으나 경직형 마비말장애에 특화된 연구는 없다(Ferguson \& Kewley-Port, 2007; Higgins \& Hodge, 2002; Liu, Tsao, \& Kuhl, 2005; Neel, 2008; Weismer, Jeng, Laures, Kent, \& Kent, 2001).

Kim, Hasegawa-Johnson과 Perlman (2011)은 영어가 모국어인 미국인 마비말장애(경직형 등의 하위 유형은 불분명) 환자 대상으로 말 명료도와 여러 음성분석 결과가 연관된다는 보고를 하면서, 모음 공간이 기여한다고 하였으나, 그 정도는 명확히 밝히지 못하였다.

국내에서는 마비말장애 환자를 대상으로 문맥적 상황에서의 말 명료도와 모음공간을 연구한 연구가 있었으나(Lee, Han, \& Park, 2010), 마비말장애 각 하위 유형, 이를테면 경직형 마비말장애의 모 음공간과 말 명료도에 대한 결과는 보고되지 않았고, 마비말장애 화자에 대한 말 명료도 평가와 음향학적 특성에 대한 단순 결과는 보고되고 있으나 아직까지 일반인 대상 청지각적 말 명료도와음향 학적 분석 간의 관계에 관한 연구들이 미약한 실정이다(Lee, 2010b).

따라서 본 연구에서는 마비말장애의 하위 유형 중 경직형 마비 말장애 환자에서, 틀구문을 사용한 문맥모음에 따른 말 명료도와 고립/문맥 모음에서의 모음공간 특성을 비교 제시하고자 한다. 이 를 위하여 경직형 마비말장애 환자군의 수행을 정상군의 수행과 비교 분석한 후, 각 집단에서 고립모음과 문맥모음 상황에서 음향 학적 분석에서의 차이 여부를 확인하고자 한다.

등간척도법에 의하면 청취자는 각 소리자극을 듣고 눈금이 그려 진 연속적인 선위에 환자의 상태에 해당하는 상태를 수로 표시하 게 된다(Schiavetti, 1992). 오랫동안 연구와 임상분야에서 널리 사 용되고 있으며, 척도 유형에 따라서도 다양한 결과해석이 제시되고 있다(Lee \& Kim, 2009). 이 검사는 다른 명료도 검사에 비해 평가 절차가 용이하며, 비용이 적게 들기 때문에 효율적이다(Schiavetti, 1992). 그러나 평가자가 가지고 있는 음성장애에 대한 고정관념으 로 인해 정확한 평가가 이루어지지 않는 경우, 양극의 점수보다는 중앙에 밀집하여 평가하는 경우와 같은 제한이 있다(Sim, 2011; Kim \& Sin, 2007; Song, 2012). 때문에 본 연구에서는 청취자로 명 료도 검사에 대한 전문적인 훈련을 받은 경험이 없으며, 마비말장 애 유형별에 따른 말 특성에 대한 전문지식이나 경험이 없는 비전 문가들에게 명료도에 대한 척도를 평가하게 하였다.

마비말장애 환자의 정확한 모음이 조음과 관련된다고 보고하였 으며, 모음공간면적에 따라 청자의 이해 정도에도 차이가 나타날 수 있으며, 환자에서 모음공간이 축소되고 중앙화되는 형태를 가진다 고 하였다(Namgung, 2008). 따라서 모음공간이 경직형 마비말장 애 환자의 말 명료도와 어떻게 관계되는지도 살펴보고자 한다.

모음공간(vowel space)은 3차원 조음공간인 성도(vocal tract)를 포먼트(formant)의 2차원적인 그림으로 비유해 인식하기 쉽게 나 타낸 것으로, 대표적으로 제 1 포먼트와 제 2 포먼트의 좌표에 점으로 나타내어 성도와 혀의 위치를 고려한 포먼트 파라미터 연구로서 (Neel, 2008), 모음 사각도로 표시하는 경우가 흔하다. 모음공간 면 적은 제 1 포먼트 $(\mathrm{F} 1$, 경험적으로 혀의 높낮이)와 제 2 포먼트 $(\mathrm{F} 2$, 경험 적으로 혀의 전후) 수치를 이용하여 사용하는 모음의 조합을 통해 측정할 수 있다. 국내 연구에서는 주로 단모음의 연장 발성을 이용하 여 음성정보나 포먼트 주파수의 특징을 살펴보는 연구가 많이 이루 어져왔으나(Lee, Park, \& Chung, 2000; Park, Park, \& Kim, 2004), 본 연구에서는 단모음 수준과 문맥 수준에서의 모음을 모두 논하였다.

모음공간 면적을 산출하는 공식은 F1과 F2 수치를 2차원적인 단 면에 두었을 때 나타나는 면적을 분할하여 직각의 선을 연결하여 수학적으로 도출한 것으로, 모음공간을 나누는 데 있어 $3,4,5$ 각형 등 다양하게 나타낼 수 있다. 본 연구의 모음공간 면적 공식은 Vorperian과 Kent (2007)가 제시한 모음 사각도 면적의 공식을 한국어 꼭지모음(corner vowels)에 맞게 유도한 것이다(Kang, Yoon, Lee, \& Seong, 2010). 모음공간 면적은 불규칙한 모음사각도의 두 꼭지 점에서 모음사각도 안쪽으로 수선의 발을 그어 교차하는 좌표의 점까지 네 개의 직각 삼각형으로 구역을 나누고, 각 공간의 면적을 합하여 완성되는 것으로 해석할 수 있다.

모음의 조음 지수(vowel articulatory index, VAI)는 마비말장애 환자들의 조음 움직임 측정에 사용되는 삼각형 모음공간 면적 또는 사각형의 모음공간 면적 수치들의 불안정과 그로 인한 통계 검정에 있어서의 둔감함을 보완하기 위해 제안된 공식이다(Skodda, Visser, \& Schlegel, 2011). 또한 모음 중앙화 비율(formant centralization ratio, FCR)은 VAI와 역수관계로, 민감도는 유지하면서, 화자 개인 간 의 변수에 의한차이를 줄여 표준화하기 위해 고안된 공식이다(Skodda et al., 2011). FCR은 VAI와 역수관계이므로 공식에서 분자에 있 는 포먼트 주파수가 증가할수록, 모음사각도의 모양은 모음공간 표 준좌표에서 중앙화된 것으로 (시각적으로) 인식되며, 이는 FCR 수 치의 증가로 이어진다. 반대로 모음사각도의 모양이 바깥으로 확장 되어 넓어질수록, $\mathrm{FCR}$ 수치는 감소되는 경향을 보인다. 마지막으로 $\mathrm{F}_{2}$ ratio $\left(\mathrm{F}_{2 / / 0 / /} / \mathrm{F}_{2 / \text { 平 }}\right)$ 는 모음사각도에서 나타나는 입술의 원순성과 평순성의 대립을 가장 나타낼 수 있는 모음/이/와/우/로 $\mathrm{F}_{2}$ ratio를 통해조음 오류를 살펴보고자 하였다(Kang et al., 2010).

\section{연구 방법}

\section{연구 대상}

본 연구의 대상자는 2010년 3월부터 2012년 11월까지 O대학병 
원 재활의학과 전문의로부터 마비말장애로 진단받고, 언어병리학 석사과정인 현직언어치료사 1 인과, 1 급 자격증을 소지한 3 년 이상 의 임상 경험이 있는 언어치료사이면서 동시에 언어병리학 전공의 박사학위 과정인 1 인(총 2인)에 의해 2005년 Duffy의 기준에 따라 경직형 마비말장애로 판단된 남자 환자군 15 명 $(\mathrm{N}=15)$ 과 정상집단 으로 마비말장애 및 기타 신경언어영역의 이상소견이 없는 남자 정 상군 15 명 $(\mathrm{N}=15)$ 을 대상으로 하였다. 환자군에서 평가 수행이 불 가능하거나 인지 및 병의 중증도 등을 고려하여 평가에 부적절한 환자들은 연구통제를 위해 제외되었으며, 마비발장애에 있어서 심 도의 환자를 제외한 경도와 중도의 환자들을 대상으로 하였다(Lee et al., 2010). 또한 실어증 여부를 판단하기 위해 실어증-신경언어장 애 선별검사(screening test for aphasia \& neurologic-communication disorders, STAND)를 통해 선별되었으며, 검사결과 실어증 및 실행증을 동반하지 않은 경우로 제한하였다. 또한 환자들의 인지기 능수준을 제한하여 간이 정신상태 검사(mini-mental state examination, MMSE) 점수는 25점 이상만을 허용하였다.

환자군 모집 시, 병원 내 담당의를 통해 사전에 연구에 대해 충분 히 설명하였고, 담당의와 환자에게 연구 참여 동의를 구하였다. 대 상자와 대상자 보호자의 보고를 통하여 일상생활에 어려움을 초 래하는 인지와 청력문제는 없음을 확인하였다. 연구대상의 정보는 다음 Table 1에 요약하였다.

\section{음향 평가 도구}

Praat (version 5.2.16), 녹음 설정(sampling rate 192,000 Hz, 16 bit, mono)이 탑재된 컴퓨터에 신호 대 잡음비 $60 \mathrm{~dB}$ 이상의 마이크 CGS-710V model (condenser, uni-directional and goose-neck type, Charis, Korea)를 연결하여 녹음 및 디지털화하였고, 컴퓨터로 녹 음 후 다운-샘플링은 하지 않았다.

\section{검사 절차}

\section{실험 장소 및 음성 녹음}

본 연구에서 환자군 음성 녹음은 $\mathrm{O}$ 대학병원 내 언어치료실 내 조용한 곳에서 실시하였으며, 환자와 마주 보는 상태로 평가를 실 시하였다. 정상군 음성 녹음은 환자군 음성 녹음이 이루어진 동일 공간에서 수행하였다.

음성 녹음 시, 발화자의 입과 마이크 사이의 거리를 $10-15 \mathrm{~cm}$, 각

Table 1. Demographic information

\begin{tabular}{lcc}
\hline & Normal group (N=5) & Patient group (N=5) \\
\hline Gender & Male & Male \\
Age (yr), mean $\pm S D$ & $65.8 \pm 10.91$ & $69.7 \pm 9.32$ \\
\hline
\end{tabular}

도는 45도로 유지되도록 하였다. 발화자가 휠체어 또는 의자에 편 안히 앉은 자세에서 입과 녹음기와의 거리, 위치, 각도를 조절하였 다. 또한 최대한 편안하고 자연스러운 상태에서 움직이지 않도록 주 의를 주고 녹음을수행하였다.

\section{말 명료도 과제}

발화과제는 우리말 꼭지모음으로 구성된 문맥모음이었으며, 실 제 항목으로는 /이것을 하드라 한다/, /이것을 해드라 한다/, /이것을 후드라 한다/, /이것을 히드라 한다/로 과제를 구성하였다. 이것은 구성된 모음의 F1값과 F2값에 불안정 영향을 최소화하면서 음성 학적 문맥모음을 통제하기 위해 모음 앞에 동시조음 현상이 작은 기식음/히를 첨가하여 발성하게 하고, 뒤에 파열음 /ㄷ/을 삽입하 여 모음구간을 닫게 한 것이다. 과제 녹음 시 대상자는 각 문맥모음 을 1 회 연습 후 4 회 반복하여 실시하였다. 이를 바탕으로 환자와 정 상군 간에 문맥모음 수준에서 말 명료도 차이가 있는지 알아보고 자하였다.

\section{모음공간 과제}

모음공간을 보기 위해 고립모음과 문맥모음으로 나누어 분석하 였으며, 고립모음은 우리말 꼭지 모음으로 /아/, /이/, / 우/, /애/의 단 모음으로 구성하였으며, 문맥모음은 2음절로 구성하였다. 녹음자 료는 4개의 우리말의 꼭지모음 /아/, /이/, /우/, /애/를 환자가 낼 수 있는 최대연장발성시간(maximum phonation time, MPT)의 측정 을 통해 1 회 연습 후 녹음하여 구하였으며, 음성의 약 $1 / 3$ 지점의 안 정구간을 선택하였다. 검사 수행에 어려움을 보일 경우 5초 이상의 쉼을 둔 후에 다시 발성을 유도하였다. 동일한 방법으로 /하드/, /해 드/,/후드/,/히드/를 4회 반복하여 실시하였다.

\section{자료 분석}

말 명료도

O대학병원 내 재활의학과 소속의 비전공자 $(\mathrm{N}=18)$ 가 듣고 5점 의 등간척도로 점수를 표시하였다. 청취자는 언어치료를 전공하지 않은 18 명의 비전문가적인 평가자가 참여하였다. 이들은 모두 병원 내 재활의학과 소속으로 남성 10 명, 여성 8 명으로 명료도 검사에 대한 훈련을 받은 경험이 없었다. 그러나 연구에 사용된 등간척도 를 사전에 숙지하고 본 연구에 참여하였다. 말 명료도 분석 시, Lee 등 (2010)의 연구방법을 참고하였으며, 등간척도 유형에 따른 말 명 료도 점수를 알아보기 위해 STAND 평가지에 기록된 5점 척도를 이용하였으며, 세부 기준도 그대로 사용하였다. 각 기준은 [5점]-극 심도(extremely severe)-말을 전혀 안 하거나 못 함, [4점]-심도(se- 
vere)-발음이 매우 불분명하여 거의 알아들을 수 없음, [3점]-중도 (moderate)-발음이 불분명하여 알아들을 수 있는 부분과 알아듣 기 어려운 부분이 혼재함, [2점]-경도(mild)-발음은 불분명하나 알 아듣는 데에는 지장이 없음, [1점]-정상(normal)-말을 알아듣는 데 전혀 어려움이 없음-으로 하였다. 청지각 평가자들은 15 명 환자의 문맥수준의 틀구문을 듣고 5점 등간척도로 점수를 표시했다.

청지각 평가자들은 컴퓨터에 연결된 스피커를 통해 일정한 크기 의 수준으로 들려주었으며, 스피커와의 거리는 $20 \mathrm{~cm}$ 로 조정하였 다. 각 발화는 1 회만 들려준 뒤 곧바로 말 명료도에 대한 척도를 산 정하도록 하였다.

\section{모음공간}

각 꼭지 모음별 연장발성을 통해 모음의 시작부에서 약 $1 / 3$ 지점 으로 안정적으로 펄스 신호(pulse bar)가 생기고, 피치, 포먼트, 강 도가 최대한 일정하게 수평이 되는 부분을 구간으로 하여 분석하 였다. Praat 설정에서 5 개의 포먼트를 계산하는 것을 표준으로 잡 고, 대상자 전원이 남자였으므로 $5,000 \mathrm{~Hz}$ 을 상한값으로 고정하였 다. 고립모음과 문맥모음별 각 4 회 반복한 값의 평균을 내어 통계에 적용하였다.

분석 파라미터는 Kang 등(2010)의 모음공간 파라미터 비교 연 구에 근거하여 다음과 같은 파라미터를 적용하였고 그 공식은 아 래와같다.

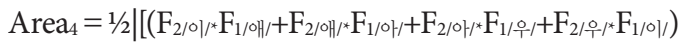

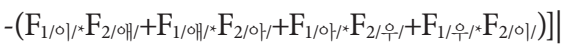

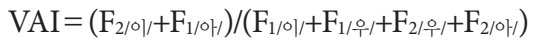

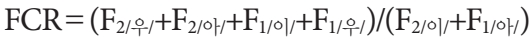

$$
\begin{aligned}
& \mathrm{F}_{2} \text { ratio }=\mathrm{F}_{2 / 0 \mid / /} / \mathrm{F}_{2 / \text { 위 }}
\end{aligned}
$$

\section{신뢰도}

청취자들의 등간척도에 대한 자료 분석에 대한 신뢰도를 검증하 기 위해 측정자 간 신뢰도 분석방법으로 SPSS version 17.0의 intraclass correlation coefficient (ICC)분석을 이용하였다. 분석 결과 측
정자간 신뢰도는 / / /,/ / /, / T/,// / 각각에 대해서 평균 측도 ICC가 각각 $.989, .989, .989, .991$ (all $p<.001$ )로, 중등도 이상으로 높게 나 타났다.

모음공간 파라미터의 자료 분석에 대한 신뢰도를 검증하기 위해 언어병리학 전공 대학원생 2 명에게 검사 절차, 기록 방법, 분석 방 법을 자세히 설명 후 전체 수집된 자료의 4 개의 음성샘플(환자군 2 개, 정상군 2개)을 임의로 선정하여 Praat 프로그램을 사용하여 포 먼트 주파수를 분석하였으며, 포먼트 주파수 분석에 대한 측정자 간 신뢰도는 평균 $98 \%$ 로 높게 나타났으며, 신뢰도 측정을 위해 사 용한 공식은 다음과 같다.

음향분석의 측정자간 신뢰도 $(\%)=($ 측정자 2 가 측정한 $\mathrm{F} 1$ 또는 F2 평균치/측정자 1 가측정한 $\mathrm{F} 1$ 또는 F2 평균치 $) \times 100$

\section{결과처리}

통계분석은 SPSS version 17.0 을 이용하였다. 환자군과 정상군의 문맥모음에 따른 말 명료도 차이를 5 점 척도로 산출된 값의 중위 수와 사분구간을 알아보기 위해 기술통계를 실시하였으며, 그 차 이를 알아보기 위해 두 집단 간에 Mann-Whitney U-test를 실시하 는 등 이후 기술된 모든 통계는 비모수 방법을 사용하였다. 모음공 간 면적의 파라미터에 대한 고립/문맥모음 상황에서 환자군과 정 상군 사이의 차이를 알아보기 위해 동일한 통계인 Mann-Whitney $U$-test를 실시하였다. 상관관계는 Spearman의 상관계수를 사용하 였다. 1 종 오류는 .05 이하로 하였다.

\section{연구 결과}

\section{문맥모음에 따른 말 명료도 점수의 차이}

본 연구에서 나타난 5점 척도를 기준으로 비전문가인 청자들이 듣고 평가한 말 명료도 평가의 기술통계량 및 검정 결과는 Table 2 에 제시된 바와 같다.

문맥모음에서의 꼭지 모음들의 명료도 중위수는 정상집단 1.20

Table 2. Speech intelligibility on a 5-point scale

\begin{tabular}{|c|c|c|c|c|c|}
\hline \multirow{2}{*}{ Vowel in context } & \multicolumn{2}{|c|}{ Normal $(\mathrm{N}=15)$} & \multicolumn{2}{|c|}{ Dysarthria (N=15) } & \multirow{2}{*}{$U$} \\
\hline & Median & IQR & Median & IQR & \\
\hline / / I & 1 & $1-1.1041665$ & 2.166667 & $1.75-2.694444$ & $2.00^{* * *}$ \\
\hline /H/ & 1 & $1-1.5$ & 2.25 & $1.694444-2.694444$ & $4.00^{* * *}$ \\
\hline /T/ & 1.027778 & $1-1.513889$ & 2 & 1.888889-3.194444 & $5.00^{* * *}$ \\
\hline $11 /$ & 1 & $1-1.958333$ & 2.33333 & $2-2.666667$ & $17.50^{* * *}$ \\
\hline
\end{tabular}

$\mathrm{IQR}=$ interquartile range.

${ }^{* * *} p<.001$. 
Table 3. Results for the acoustic analysis

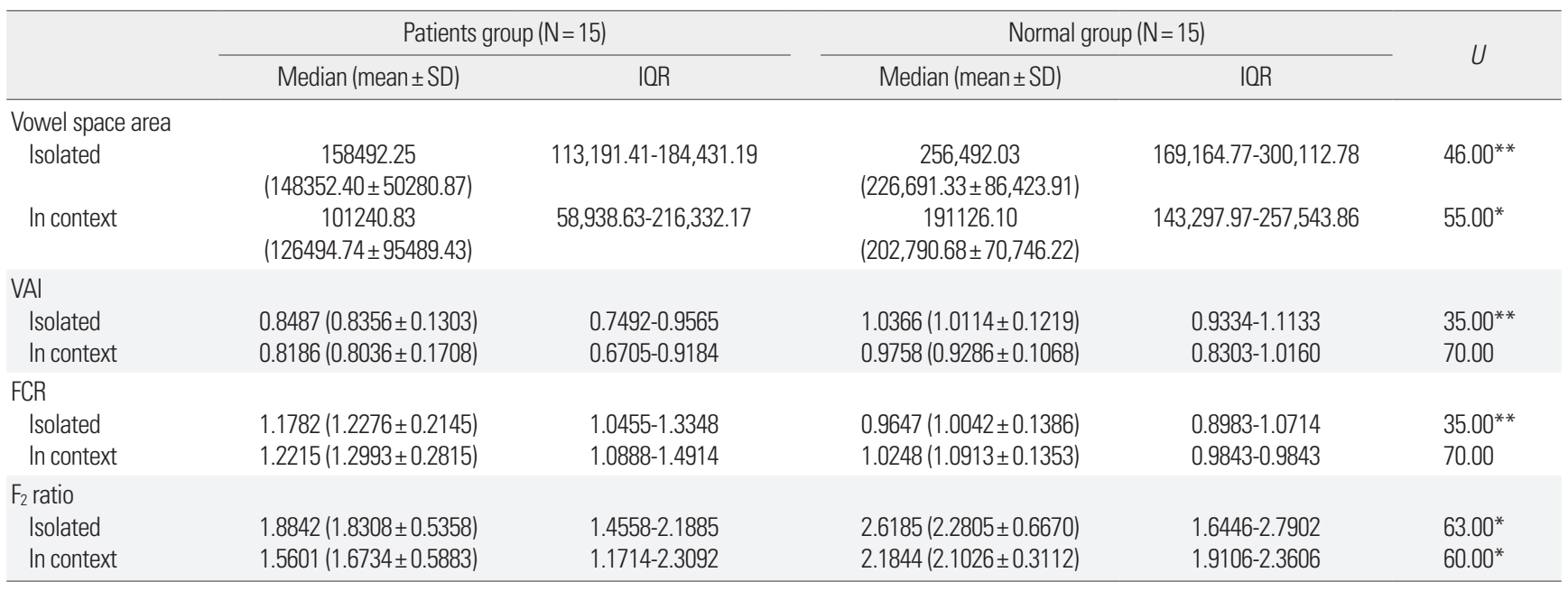

$\mathrm{IQR}=$ interquartile range; $\mathrm{VAl}=$ vowel articulatory index; $\mathrm{FCR}=$ formant centralization ratio. ${ }^{*} p<.05,{ }^{* *} p<.01$.

점, 경직형 마비말장애 집단은 2.07점으로 경직형 마비말장애 집단 의 명료도가 정상집단에 비해 좋지 않은 것으로 나타났다. 집단 간 차이를 알아보기 위한 Mann-Whitney $U$-test에서 검정된 모든 모 음에서 환자군의 말 명료도가 정상인에 비해 나쁜 것으로 나타났다 $(U(/ / /)=2.000, p<.001 ; U(/ / /)=4.000, p<.001 ; U(/ T /)=5.000$, $p<.001 ; U(/ / /)=17.500, p<.001)$.

\section{집단 간 고립모음에 따른 모음공간 파라미터}

집단(환자군/정상군)에 따른 모음공간 파라미터에 대한 기술통 계량 및 Mann-Whitney U-test 결과는 Table 3에 제시된 바와 같다.

집단에 따른 모음공간 파라미터 결과를 살펴보면 결과는 다음 과 같다. 고립모음의 모음공간의 경우 정상군의 총 면적은 중위수 $256,492.03$, 환자군 총 면적은 중위수 $158,492.25$ 로 나타났다. 고립 모음에서 Mann-Whitney U-test를 실시하여 집단 간 유의미한 차 이를 확인했다 $(U=46.00, p<.01)$.

문맥모음에서의 모음공간의 경우 정상군의 총 면적은 중위수 $191,126.1$, 환자군 총 면적은 중위수 $101,240.83$ 으로 나타났다. 문맥 모음에서 모음공간 면적의 집단 간 차이를 알아보기 위해 MannWhitney $U$-test를 실시하여 집단 간 유의미한차이를 확인했다 $(U=$ $55.00, p<.05)$.

$\mathrm{VAI}$ (또는 $\mathrm{FCR}$ )의 고립 환경의 모음의 경우, 정상군과 환자군의 차이를 알아보기 위한 Mann-Whitney $U$-test를 실시한 결과 집단 간 유의미한 차이를 확인했고 $(U=35.00, p<.05)$ 문맥모음에서는 통계적 차이를 확인할 수 없었다.

$\mathrm{F}_{2}$ ratio는 고립 모음에서 정상군과 환자군 사이에 유의미한 차
이를 보였고 $(U=63.00, p<.05)$, 문맥 모음에서도 유의미한 집단 간 차이를 보였다 $(U=60.00, p<.05)$ (Table 3).

말 명료도와 음향분석과의 상관관계는 환자군 15 명에서 / / / 의 말 명료도와 $\operatorname{VAI}(\mathrm{FCR}$ 도 같은 Spearman's $r$ 값) 사이만 유의미한 상 관관계를 보여주었다(Spearman's $\rho$ of isolated vowel $=.551, p<.05$, Spearman's $\rho$ of vowel in context $=.532, p<.05$ ).

\section{논의 및 결론}

본 연구는 마비말장애로 진단받은 환자 중 경직형 마비말장애 15 명 $(\mathrm{N}=15)$ 과 정상군 15 명 $(\mathrm{N}=15)$, 총 30 명을 대상으로 문맥모음 에서의 말 명료도 지표와 고립/문맥 모음에서의 모음공간 파라미 터를 분석함으로서 경직형 마비말장애 환자들에 나타나는 말 명 료도 감소와 모음공간 파라미터 특징을 알 수 있었다. 정상인에 비 해 경직형 마비말장애 환자에서 저하된 말 명료도와 정상인과 환 자사이의 모음공간 파라미터 차이를 알 수 있었다.

말 명료도 결과는 동일한 환경의 문맥모음에서 정상집단이 환자 집단보다 명료도가 좋다고 할 수 있으며, 경직형 마비말장애로 인 한 말 명료도 감소가 확인되었다. Pyo와 $\operatorname{Sim}$ (2005)은 명료도 향상 연구에서 경직형 마비말장애는 음도 및 강도의 변화가 단조롭고 대 체로 음도가 낮아지며, 긴장성이 심하게 동반된 쉰 목소리를 내고, 음도 일탈과 짧은 호흡으로 인한 짧은 발화가 특징으로 이는 발성 및 발화를 어렵게 한다고 보고하였다. 이를 긴장성에 의한 모음공 간 축소로 연결해 생각해 볼 수 있겠다. 즉, 음향학적인 결과와 임상 가가 상상하는, 실제 축소된, 성도 이미지를 연결할 수 있겠고 이를 
아래에서 자세히 논한다.

집단 간 음절단위의 증가에 따른 모음공간 파라미터 차이를 보 기 위해 4 개의 모음공간 파라미터들의 수치를 측정한 본 연구의 해 석은 다음과 같다.

첫째, 경직형 마비말장애 환자의 모음공간 면적은 고립과 문맥 환경 모두에서 유의미하게 작게 나타났고, 문맥모음보다 고립모음 에서 더 통계적으로 유의한 경향이 관찰됐다. 이러한 결과는 정상 군이 환자군보다 더 넓은 모음공간을 보존하였음을 정량적으로 보 여주며, 고립과 문맥모음 모두에서 이를 조음기관에 의해 이루어진 성도의, 정상군과 환자군 사이의, 실제 차이로 유추할 수 있도록 해 준다. 또한 고립 모음에서의 차이가 문맥모음에서의 차이보다 더 뚜렷한 경향을 확인할 수 있었다.

둘째, $\mathrm{VAI}$ 는 고립과 문맥모음 환경 모두에서 환자군에서 정상군 에 비해 유의미하게 작게 나타났고, 문맥모음보다 고립모음에서 더 유의한 경향이었다. 이러한 결과는 고립모음과 문맥모음에 따른 집 단 간 VAI 수치 차이를 통해서 경직형 마비말장애 환자군 모음 조 음의 중앙화 현상을 보여준다. 이는 Ferrand (2006)가 마비말장애 환자들의 모음이 중설화된 포먼트 패턴으로 변화된다고 한 해외 연구결과와 합치된다.

셋째, $\mathrm{FCR}$ 은 고립모음과 문맥모음 환경에서 모두 환자군에서 정 상군에 비해 유의미하게 크게 나타났고, 문맥모음보다 고립모음에 서 더 유의한 경향이었다. 이러한 결과는 FCR이 VAI와 역수관계 를 보이므로 같은 양상으로 이해할 수 있다. 즉 FCR 수치의 증가는 경직형 마비말장애 환자군이 정상군에 비해 모음의 중앙화 현상이 두드러짐을 말한다. Ferguson과 Kewley-Port (2007)의 연구와 마 찬가지로 모음공간의 중앙화가 나타난 결과를 도출하였으며, 이는 전술한 VAI에 대한 해석과 동일하다.

넷째, $\mathrm{F}_{2}$ ratio는 문맥모음 환경에서 환자군에서 정상군에 비해 유의미하게 작게 나타났고, 통계적 지표도 고립모음보다 문맥모음 에서 더 유의한 경향이었다. $\mathrm{F}_{2}$ 값은 혀의 전후 위치에 따라 변한다 고 하며 정상군의 $\mathrm{F}_{2}$ 값과 마비말장애 $\mathrm{F}_{2}$ 값의 차이도 커지게 된다 (Lee, 2010a)는 설명과 일치됨을 보인다. 이러한 결과는 정상군과 경 직형 마비말장애 환자군에서 혀의 구강 내에서의 전방성의 차이를 보여주며 이는 혀의 전후 움직임 또는 입술의 원순성과 같은 조음 기관의 움직임과 직접적인 연관성을 보인다고 해석할 수 있다.

다섯째, 기존 연구에서 주로 사용한 고립모음의 분석에 추가로 본 연구에서와 같은 문맥모음에서도 비슷한 결과를 가져올 수 있 음을 보인 의의가 있겠다.

여섯째, 본 연구 결과에서 경직형 마비말장애에서 말 명료도와 모음공간 관련 파라미터 사이의 관계는 상관의 경향성은 보였으나,
많은 파라미터에서 통계적 유의성까지 뚜렷하게 나타나진 않았다. 하지만 VAI, FCR는 통계적 유의성이 관찰되었다. 이를 고려할 때, 말 명료도의 한 구성요소로서 모음공간 면적 등의 음향학적 변수 가 영향을 미칠 가능성을 확인하는 데 성공하였지만(VAI, FCR), 전체 파라미터에서 확인하지는 못하였기 때문에, 그 외 언어적 요 소의 중요성(Hustad, 2008; Kim et al., 2011) 또한 말 명료도에 중요 할 수 있겠다는 해석도 역시 가능하다. 또한 모음공간 면적 그리고 모음공간과 연관된 파라미터들만을 고려할 때, 정상인과 경직형 마비말장애에서의 차이를 보인 통계 분석에서는 명확한 차이를 보 였기 때문에, 경직형 마비말장애 환자에서 정상인에 비해, 개인차 에 의한 예외를 뛰어넘는 집단 비교에서, 모음공간이 실제 성도에 서 줄어드는 현상으로 일관성 있게 해석할 수 있겠다.

전반적으로 경직형 마비말장애 환자군은 정상군에 비해 모음공 간 면적이 좁았고 VAI 수치는 작았으며, $\mathrm{FCR}$ 과 $\mathrm{F}_{2}$ ratio 수치는 커 졌다. Platt, Andrews, Young과 Quinn (1980)은 말 명료도에 영향 을 미치는 화자의 변인으로 줄어든 모음공간(vowel space)을 이야 기 하였으며, Ferguson과 Kewley-Port (2007)과 Lee (2010a)은 모음 공간 면적이 말 명료도와 상관이 있다고 보고하였고, Neel (2008) 과 Kang 등(2010) 역시 관련 파라미터들이 모음공간 면적과 상관 을 보여준다고 하였다. 이런 문헌조사 결과가 마비말장애의 세부형 태인 경직형에서도 적용됨을 본 연구를 통해서 볼 수 있었고, 그 객 관적 준거 또한 제시할 수 있었다.

본 연구의 제한점을 더욱 고찰하면서 향후 연구를 염두에 둔 제 언을 기술한다.

첫째, 본 연구는 경직형 마비말장애 환자군에 중점을 두고 말 명 료도와 모음공간의 특성을 살펴보았다. 음향분석 지표들 사이의 높은 상관(not described: 내적일관도 높음)에 비해서, 마비말 장애 의 임상적 말 명료도와 상관관계가 있는 음향분석 지표로는 VAI (FCR)만 제시되었고, 모음공간 면적과 $\mathrm{F}_{2}$ ratio는 통계적 경향성만 보이는 데에 그쳤다. 좀더 많은 대상자를 대상으로 하여 검정하는 향후 연구에서 더 정확히 판별할 수 있을 것이다.

둘째, 경직형 마비말장애 이 외에 다른 하위유형에 대한 접근이 필요하다는 점이다. 음향학적 측정치와 말 명료도와의 관계에서 각 하위유형의 특성을 고려한 연구가 지속되어야 할 것이며 본 연 구 결과를 포함하여 향후 연구는 마비말장애의 말 명료도 평가와 중재에 기반을 마련할 수 있는 규준의 하나로 제시될 수 있을 것이 라사료된다.

셋째, 말 명료도의 다양한 평가방식(등간 척도 방식을 본 연구에 서 사용하였고, 전사 방식은 다른 연구에서 볼 수 있음.)에 대한 비 교 연구, 평가과제의 언어학적 특성을 본 연구와 달리한 연구, 그리 
고 모음공간의 면적에 따른 파라미터 이 외에 포먼트 모양, 발성개 시시간(voice onset time), 모음산출길이 등 다양한 음향학적 분석 치를 이용한 접근을 통해 마비말장애 환자에 대한 접근과 연구가 지속되어야 할 것이다.

지금까지 본 연구는 고립 모음과 문맥 모음에 따른 집단(환자군) 정상군)별 말 명료도와 모음공간 파라미터(vowel space area, VAI, $\mathrm{FCR}, \mathrm{F}_{2}$ ratio)의 수치를 통해 차이를 고찰하고, 또한 향후 이용 가 능한 준거를 마련하였다. 이러한 결과가 경직형 마비말장애 환자의 말 명료도 변화에 대한 이해 및 평가와 중재에 보탬이 될 것을 기대 한다. 또한 현재 국내에서는 마비말장애 유형별 접근을 통한 연구 가 제한적이며, 마비말장애 전체에 대한 연구가 주로 이루어져 있었 다. 따라서 본 연구가 그 외 마비말장애 하위 유형별 다양한 연구에 도움이 되기를 기대한다.

\section{REFERENCES}

Duffy, J. R. (2005). Motor speech disorders: substrates, differential diagnosis and management (2nd ed.). St. Louis, MO: Elsevier Mosby.

Ferguson, S. H., \& Kewley-Port, D. (2007). Talker differences in clear and conversational speech: acoustic characteristics of vowels. Journal of Speech, Language, and Hearing Research, 50, 1241-1255.

Ferrand, C. T. (2006). Speech Science: an integrated approach to theory and clinical practice (2nd ed.). Boston, MA: Pearson/Allyn and Bacon.

Higgins, C. M., \& Hodge, M. M. (2002). Vowel area and intelligibility in children with and without dysarthria. Journal of Medical Speech-Language Pathology, 10, 271-277.

Hustad, K. C. (2006). A closer look at transcription intelligibility for speakers with dysarthria: evaluation of scoring paradigms and linguistic errors made by listeners. American Journal of Speech-Language Pathology, 15, 268-277.

Hustad, K. C. (2007). Effects of speech stimuli and dysarthria severity on intelligibility scores and listener confidence ratings for speakers with cerebral palsy. Folia Phoniatrica et Logopaedica, 59, 306-317.

Hustad, K. C. (2008). The relationship between listener comprehension and intelligibility scores for speakers with dysarthria. Journal of Speech, Language, and Hearing Research, 51, 562-573.

Kang, Y., Yoon, K., Lee, H., \& Seong, C. (2010). A comparison of parameters of acoustic vowel space in patients with Parkinson's disease. Journal of the Korean Society of Speech Sciences, 2, 185-192.

Kim, H., Hasegawa-Johnson, M., \& Perlman, A. (2010). Vowel contrast and speech intelligibility in dysarthria. Folia Phoniatrica et Logopaedica, 63, 187-
194.

Kim, S., \& Sin, J. (2007). Articulatory and phonological disorders. Seoul: Sigma Press.

Lee, O. (2010a). Voice education for dysarthria patients (due to brain injury). Daegu: JoongWoe Press.

Lee, O. (2010b). Speech intelligibility and vowel space area. Cogito, 68, 7-26.

Lee, O., Han, J., \& Park, S. (2010). Speech intelligibility in syllables and vowel space according to dysarthric severity. Journal of the Korean Society of Speech Sciences, 2, 85-92.

Lee, O., \& Kim, S. (2009). A comparison of three equally-appearing interval scales for auditory-perceptual evaluation: preliminary study. Journal of Speech-Language Hearing Disorders, 18, 1-16.

Lee, O., Park, S., \& Chung, O. (2000). The acoustic characteristics of vowels in the patients with spastic dysarthria. Journal of Speech-Language Hearing Disorders, 9, 171-177.

Liu, H. M., Tsao, F. M., \& Kuhl, P. K. (2005). The effect of reduced vowel working space on speech intelligibility in Mandarin-speaking young adults with cerebral palsy. Journal of the Acoustical Society of America, 117, 3879-3889.

Namgung, W. (2008). The acoustic characteristics of vowel in patients with dysarthria (Master's thesis). Wongwang University, Iksan, Korea.

Neel, A. T. (2008). Vowel space characteristics and vowel identification accuracy. Journal of Speech, Language, and Hearing Research, 51, 574-585.

Park, J. E., Park, E. S., \& Kim, H. H. (2004), A study of acoustic characteristics of vowels in preschool cerebral palsy children with spastic diplegia. Korean Journal of Communication Disorders, 9, 116-128.

Platt, L. J., Andrews, G., Young, M., \& Quinn, P. T. (1980). Dysarthria of adult cerebral palsy. I: intelligibility and articulatory impairment. Journal of Speech, Language, and Hearing Research, 23, 28-40.

Pyo, H. Y., \& Sim, H. S. (2005). The research on the improvement of intelligibility for the patients with dysarthria: literature review. Special Education Research, 4, 35-60.

Schiavetti, N. (1992). Scaling procedures for the measurement of speech intelligibility. In R. D. Kent (Ed.), Intelligibility in speech disorders (pp. 11-34). Philadelphia, PA: John Benjamins.

Sim H. (2011). Characteristics of speech intelligibility and the vowel space in patients with Parkinson's disease (Master's thesis). Hallym University, Chuncheon, Korea.

Skodda, S., Visser, W., \& Schlegel, U. (2011). Vowel articulation in Parkinson's disease. Journal of Voice, 25, 467-472.

Song, H. (2012). Effects of phonetic complexity and articulatory severity on per- 
centage of correct consonant and speech intelligibility in adults with dysarthria (Master's thesis). Ewha Womans University, Seoul, Korea.

Vorperian, H. K., \& Kent, R. D. (2007). Vowel acoustic space development in children: a synthesis of acoustic and anatomic data. Journal of Speech, Lan- guage, and Hearing Research, 50, 1510-1545.

Weismer, G., Jeng, J. Y., Laures, J. S., Kent, R. D., \& Kent, J. F. (2001). Acoustic and intelligibility characteristics of sentence production in neurogenic speech disorders. Folia Phoniatrica et Logopaedica, 53, 1-18. 


\section{국문초록}

\section{경직형 마비말장애의 말 명료도와 모음공간 특성}

\section{김성윤 ${ }^{1}$ 김정환 ${ }^{2}$ 고도흥 ${ }^{3}$}

'두루바른사회적협동조합 언어치료실, ${ }^{2}$ 국립재활원, ${ }^{3}$ 한림대학교 자연대학 언어청각학부

배경 및 목적: 마비말장애 환자는 정상인에 비해 말 명료도가 저하되어 있으며, 정상인에 비해 모음공간 파라미터가 다르다고 보고되 었다. 마비말장애 중 경직형에서 말 명료도에 대한 기초 자료와 모음공간의 음성학적 분석에 대한 기준 수치를 제시하고자 한다. 방법: 문맥모음에 따른 말 명료도를 경직형 마비말장애로 분류된 환자군 15 명과 정상군 15 명, 총 30 명의 남자를 대상으로 하여 비교하였고, 동일한 환자군 내에서 모음공간과 관련 파라미터(vowel articulatory index [VAI], formant centralization ratio [FCR], $\mathrm{F}_{2}$ ratio)를 비교 하였다. 결과: 문맥모음 수준의 말 명료도 등간척도는 정상군 중위수 1.02 점, 환자군 중위수 2.07 점으로 나타나 정상군보다 환자군에서 더 알아듣기 힘든 것으로 나타났다( $p<.001) .4$ 개의 모음공간 파라미터에서 경직형 마비말장애 환자군은 정상군에 비해 모음공간 면 적이 좁았고 $\mathrm{VAI}$ 수치는 작았으며, $\mathrm{FCR}$ 과 $\mathrm{F}_{2}$ ratio 수치는 컸다 $(p<.05)$. 논의 및 결론: 본 연구를 통해 경직형 마비말장애 환자의 말 명 료도 저하를 보았고, 모음공간 파라미터의 객관적인 준거를 제시하여 경직형 마비말장애 음향의 정상인과의 차이를 정량적으로 확인 할수 있었다.

핵심어: 마비말장애, 모음공간, 명료도, 음향분석

이 논문은 2009 년도 강원대학교병원/강원대학교 의학전문대학원의 연구비 지원으로 저술되었으며, 제 1 저자의 석사학위 논문 내용에 근거함.

\section{참고문헌}

강영애, 윤규철, 이학승, 성철재(2010). 파킨슨병 환자의 음향 모음공간 파라미터 비교. 말소리와음성과학, 2, 185-192.

김수진, 신지영(2007). 조음음운장애. 서울: 시그마프레스.

남궁원(2008). 마비말장애 환자의 모음 산출에 대한음향음성학적 특성 연구. 원광대학교대학원 석사학위논문.

박지은, 박은숙, 김향희(2004), 학령전기 경직형 하지마비 아동이 산출한 모음의 음향음성학적 특징. 언어청각장애연구, 9, 116-128.

송한내(2012). 조음복잡성 및 조음중증도에 따른 마비말장애인의 자음정확도와 말명료도. 이화여자대학교대학원 석사학위논문.

심희정(2011). 파킨슨병 환자의 말 명료도와모음공간특성. 한림대학교대학원 석사학위논문.

이옥분(2010). (뇌손상으로 인한) 마비말장애 발성과 발화지도. 대구: 도서출판 중외.

이옥분(2010). 말소리 명료도와 모음공간면적의 상관성. 코기토, 68, 7-26.

이옥분, 김소연(2009). 음성장애 청지각적 평가를 위한 등간척도법 비교. 언어치료연구, 18, 1-16.

이옥분, 박상희, 정옥란(2000). 경직형 운동구어장애자의 모음의 음향학적 특성. 언어치료연구, 9, 171-177.

이옥분, 한지연, 박상희(2010). 마비말장애 심각도에 따른 음절단위 말 명료도와 모음공간. 말소리와음성과학, 2, 85-92.

표화영, 심현섭(2005). 마비성 말 장애의 명료도 향상을 위한 연구 동향: 문헌적 고찰. 특수교육, 4, 35-60. 